\title{
Analysis on Non-Cash Settlement Pattern Applied in Financial Management of Universities
}

\author{
Jiaqing LU \\ Accounting Department, Shenyang Aerospace University, \\ Shenyang 110136, China \\ E-mail: 5028851@qq.com
}

Keywords: non-cash settlement, college, financial management

\begin{abstract}
As the alternative of the traditional cash settlement, non-cash settlement has the inimitable advantages of high efficiency, low cost and high speed, compared with cash settlement. The non-cash settlement is the result in this era with rapid development of information society, an important way to improve financial management, and the inevitable trend of reforms for university financial management means. In this paper, the author discusses about various non-cash settlement patterns corresponding to different business types for university financial settlement, analyzes the advantages for universities to implement non-cash settlement, and makes in-depth thinking on precautions in the process of non-cash settlement of universities.
\end{abstract}

In recent years, the running funding and research funding of universities are increasing as enrollment and scale continue to expand, the same with the volume of business financial settlement work, especially the amount of cash during settlement; the traditional cash settlement is difficult to meet the requirements from current socio-economic development and status of financial management in universities. Thus, it is urgent to create innovative financial management tools and to minimize the amount of cash used in financial settlement business of universities, thereby increasing work efficiency and reducing costs of financial management, and then fully realizing non-cash settlement in universities.

\section{Specific patterns of non-cash settlement in universities}

For specific business of university financial settlement, since different types of business involves different objects and business processes, different non-cash settlement patterns need be taken. Generally speaking, non-cash settlement patterns in universities can be achieved from the following aspects:

(I) Income Aspect

The income aspect of non-cash settlement in universities mainly include teachers' vertical \& horizontal subject income, students' tuition \& accommodation fees, sporadic payments and recharge money from Common-Card business.

1. Teachers' vertical \& horizontal subject income

As the money involved in teachers' vertical and horizontal subjects are in large amounts and from public units, the paying units usually pay the research funds by bank wire transfer or check to schools' bank accounts to ensure the safety of large sums of money.

2. Students' tuition \& accommodation fees

Students' tuition \& accommodation are mainly achieved through bank debit batch, which is generally completed by bank staff, but may also be done by finance staff of universities through online banking when conditions allow.

3. Sporadic income

Sporadic payments from resources inside and outside the school can be charged directly into school accounts via POS machines.

4. Recharge money from Common-Card business

Universities work with banks or software development companies to install in the campus 
some self-service transfer machines through which teachers and students can transfer any amount of money they want out of their bank cards into their Common-Card. With the Common-Card students can pay Internet-surfing fees, teachers and students can pay money for meals in the school cafeteria, shopping in the stores, bathing in the bath, etc.

(II) Outcome Aspect

1. Daily reimbursement

Currently, in addition to checks and wire transfer settlement, most universities gradually use financial business cards for non-cash settlement of daily reimbursement. Universities work with some banks to deal with staff' reimbursement in business cards through a combination of a zero balance treasury payment system, in order to achieve non-cash settlement of financial daily reimbursement in universities.

2. Payment of staff's associated wages and salaries

Payment of staff's associated wages and salaries is mainly made through the organic combination of university payroll system with online banking system. Financial staff responsible for managing salaries will extract the data about the list of salary-taking persons and other relevant information from the payroll system, and then transfer the data together with the money to be paid into the Bank; the Bank staff will finish the non-cash payment of staff's associated wages and salaries.

3. Payment of students' scholarships and related grants

Payment of students' scholarships and related grants is made like this: to extract relevant data from the student fee management system, and then pay the amount of money to be paid directly into a student's bank card through the bank on behalf of the school.

\section{The practical significance of non-cash settlement in universities}

Compared with the traditional cash settlement, non-cash settlement implemented in universities has a very important practical significance for raising work efficiency, reducing management costs, and regulating the monitoring of funds, which is embodied in the following aspects:

1. Raise financial efficiency and effectively avoid settlement risk

For teachers and students, the non-cash settlement implemented in the university reflects the concept of "people-oriented" mission of the university. Such convenient, quick and simple settlement pattern not only saves precious time of teachers and students, but also saves the inconvenience of carrying large amounts of cash for them. Meanwhile, the non-cash settlement realizes the zero inventory for cash accounting management, completely avoids the unforeseen risks in the process of cash flow, ensures the safety of cash, and effectively avoid the risk of cash settlement.

2. Clear and detailed transaction records, to facilitate an orderly future reference

Since non-cash settlement pattern is done through computers, POS machines or other data storage machines, each payment is recorded and traced, easy to check and correct the errors. After the implementation of non-cash settlement, accountants need not handle cash, but make the payments or settlement by way of bank transfer, so the ins and outs of each payment will leave traces to be investigated.

3. Reduce financial management costs and raise efficiency in the use of funds

Non-cash settlement pattern plays an active role on the financial sector to strengthen cash management, raise work efficiency, enhance financial management and improve financial management mechanisms in the university. Meanwhile, for the establishment of sound financial management and effective financial management system, from the perspective of cost theory, compared with the traditional cash settlement, non-cash settlement saves financial management and transaction costs, raises the cash flow speed, and improves capital efficiency.

4. Break through time and space constraints, to achieve dynamic management of settlement

Cash settlement requires handling persons deal with the business within the specified time frame and fixed places, business process subject to the constraints of time and space. The non-cash 
settlement pattern just makes up for this limitation. Non-cash settlement pattern breaks the limitations of time and space, achieves dynamic management of settlement, facilitates the majority of faculty and students, and enhances the service of the financial sector.

\section{Thoughts on non-cash settlement pattern implemented in universities}

Compared with traditional cash settlement pattern with the short-comings of huge workload, low efficiency and poor security, non-cash settlement pattern implemented in universities has unparalleled advantages and has become a trend of financial settlement in universities. However, non-cash settlement as a new star need be continuously tested by practice for its promotion and development, so that it continues to be improved. Therefore, as a new star and a new settlement pattern, non-cash settlement still need be paid attention and thought about in future applications in universities:

1. A stable network platform and reliable data are the foundation conditions to implement non-cash settlement in universities.

In the daily business processing, finance staff should keep close contact with software development departments and relevant banks to do routine maintenance of the network and ensure smooth and stable network. In addition, the reliable financial data is in favor of the orderly and safe running of non-cash settlement, so data providing staff must be very careful, while data checking financial staff must be dedicated, strict, careful in review, and avoid error messages such as inaccurate amount, duplication of number/name, etc. as much as possible, thus ensuring the authenticity and accuracy of the balance sheet data, and laying a solid foundation for the implementation of non-cash settlement pattern in universities.

2. Unified innovative ideas and adequate funding are the fundamental premise to implement non-cash settlement in universities.

All new things are not easy in their initial stage, and will inevitably encounter various questions and resistance. Non-cash settlement as a new settlement pattern, of course, is no exception. Thus, schools shall attach great importance: under the premise of ensuring adequate funding, continuously change and unify the thoughts of not only school leaders and finance staff, but more importantly the thoughts of all beneficiaries.

3. Comprehensive financial officers and a sound regulatory framework are necessary to implement non-cash settlement in universities.

Non-cash settlement replacing the traditional cash settlement is the inevitable result of social development and strong evidence of new things constantly replacing old things. It not only puts forward higher requirements on financial staff, but also poses more challenges for the related original financial system. To implement non-cash settlement in universities, financial staff shall have a comprehensive level of business and computer skills, so they need constant self-learning and training on professional skills.

In addition, to implement non-cash settlement, supports of appropriate financial rules and regulations are essential, so universities shall constantly improve the non-cash settlement system, strengthen internal controls, and streamline business processes, thus preventing financial risks, eliminating financial loopholes, and ensuring the safety of the use of funds.

4. Timely data backup and solid network environment are a security support to implement non-cash settlement in universities.

To ensure the security of financial data and funding, we shall make backup timely for relevant data, and strengthen the network security of financial server by installing network firewall onto the server to prevent the server from viruses and then avoid loss of financial data, stealing of online banking passwords and other situations. Meanwhile, we shall use double servers for hot backup, so that if one server fails, the other server can continue to work without affecting the normal operation of the financial system, thus ensuring the smooth and orderly running of non-cash settlement.

In conclusion, as a new financial settlement pattern, non-cash settlement emerges in response to the state's financial situation and economic development, in line with the development of major 
policies and financial direction of the country. Non-cash settlement has the incomparable superiority in raising financial efficiency, reducing financial management costs, and avoiding risks of income and expenditure account, etc. which the cash settlement does not have, but at the same time, we should also take full consideration of precautions in the implementation of non-cash settlement, and face the difficulties and challenges encountered in the implementation process.

\section{References}

[1] YL.Liu, "Colleges and universities to implement "cashless" reimbursement analysis”, Economist, 2012 (9).

[2] J.Chen, "Research on risk management of non cash reimbursement", Journal of Wuhan University of Technology, 2012 (6).

[3] WH.Jin, "Without the necessity of cash management in enterprise financial management", The modern information economy, 2012 (3).

[4] Y.Yang, Y.Zhang, "No cash settlement in vocational colleges in the financial”, Journal of Beijing Polytechnic College, 2012 (4).

[5] LM.Hou, “College financial reimbursement audit problems and countermeasures”, Business accounting, 2010 (9).

[6] QP.Li, “On cashless reimbursement management applications in the enterprise”, Modern commercial, 2011 (2). 